\title{
CONTENTS OF VOLUME 30
}

\section{R. P. AKABARI: See L. K. PATEL}

ALAN L. ANDREW: Correction of finite difference eigenvalues of periodic SturmLiouville problems

L. BASS: See A. J. BRACKEN

A. R. BESTMAN: Unsteady low Reynolds number flow in a heated tube of slowly varying section

J. R. BLAKE: The Kelvin impulse: application to cavitation bubble dynamics

P. J. BLENNERHASSETT: See B. J. KACHOYAN

M. I. G. BLOOR: $S e e$ A. C. KING

A. J. BRACKEN, H. S. GREEN and L. BASS: Groups defined on images in fluid diffusion

A. J. BRACKEN, K. HOLMÅKER, L. V. MALONEY and L. BASS: Flux ratios for biological membranes and reciprocity theorems for linear operators

P. BREEN and W. HENDERSON: Dominated strategies in searching for evolutionary stable strategies

W. L. CHAN and YU-KUN ZHENG: Exact solutions of nonlinear evolution equations of the AKNS class

B. D. CRAVEN: Boundary conditions in optimal control

U. K. DAVE: See L. K. PATEL

PHIL DIAMOND: Stochastic models for interference between searching insect parasites

G. F. FITZ-GERALD and N. A. McDONALD: An asymptotic solution of an integro-differential equation arising in magnetic coupling through thin shield walls

ELIAS FLYTZANIS and NIKOLAOS S. PAPAGEORGIOU: On the existence and sensitivity analysis of optimal capital accumulation paths in continuous time, infinite horizon models

CHARLES N. FRIEDMAN: Some remarks on Pauli data in quantum mechanics

C. J. GOH: See K. L. TEO

H. S. GREEN: See A. J. BRACKEN

R. GRIMSHAW: An analysis of the impact of T. M. Cherry's work on asymptotic expansions

A. J. HALL and G. C. WAKE: A functional differential equation arising in modelling of cell growth

NEVILLE HATHAWAY: See JOHN RICKARD

W. HENDERSON: See P. BREEN

JAMES M. HILL and ALEX McNABB: On the problem of uncoupling systems of linear differential equations

K. HOLMÅKER: See A. J. BRACKEN

HONG HUIMIN: See CHEN ZHAOLIN 
D. G. HURLEY: Mathematical research at the Aeronautical Research Laboratories 1939-1960

D. J. IVERS: On generalised toroidal-poloidal solutions of vector field equations

ZHANG JIFENG: See CHEN ZHAOLIN

B. J. KACHOYAN and P. J. BLENNERHASSETT: On the finite Dean problem: linear theory

A. C. KING and M. I. G. BLOOR: A note on the free surface induced by a submerged source at infinite Froude number

D. K. KULSHRESTHA: Duality between distant point and median of a tree network space

K. A. LANDMAN: A boundary integral method for contaminant transport in two adjacent porous media

WEN-WEI LIN and GERHARD LUTZER: An application of the homotopy method to the generalised symmetric eigenvalue problem

M. A. LUKAS: Assessing regularised solutions

230

GERHARD LUTZER: See WEN-WEI LIN

L. V. MALONEY: See A. J. BRACKEN

N. A. McDONALD: See G. F. FITZ-GERALD

ALEX McNABB: See JAMES M. HILL

J. M. MURRAY: Optimal control problems with elastic collisions

M. R. OSBORNE and TANIA PRVAN: Smoothness and conditioning in generalised smoothing spline calculations

M. R. OSBORNE: See TANIA PRVAN

NIKOLAOS S. PAPAGEORGIOU: See ELIAS FLYTZANIS

L. K. PATEL, R. P. AKABARI and U. K. DAVE: Radiating Demianski-type metrics and the Einstein-Maxwell fields

TANIA PRVAN and M. R. OSBORNE: A square-root fixed-interval discrete-time smoother

TANIA PRVAN: See M. R. OSBORNE

JOHN RICKARD and NEVILLE HATHAWAY: A flexible strategy for warring duopolists

G. K. ROBINSON: A method of accelerating stationary iterative methods for solving linear systems

M. VAN ROOYEN, M. SEARS and S. ZLOBEC: Constraint qualifications in input optimisation

M. SEARS: See M. VAN ROOYEN

MAITHILI SHARAN, M. P. SINGH and BALBIR SINGH: A mathematical model for the process of gas exchange in lung capillaries using $n$ 'th order one-step kinetics of oxygen uptake by haemoglobin

BALBIR SINGH: See MAITHILI SHARAN

M. P. SINGH: See MAITHILI SHARAN

K. K. TAM: Travelling wave solutions for rich flames of reactive suspensions

K. L. TEO and C. J. GOH: A computational method for combined optimal parameter selection and optimal control problems with general constraints

E. O. TUCK: The wave resistance formula of J. H. Michell (1898) and its significance to recent research in ship hydrodynamics

G. C. WAKE: See A. J. HALL 
E. M. E. ZAYED: Some asymptotic spectral formulae for the eigenvalues of the Laplacian

CHEN ZHAOLIN, HONG HUIMIN and ZHANG JIFENG: Controllability of generalised dynamical systems with constrained control

YU-KUN ZHENG: See W. L. CHAN

S. ZLOBEC: See M. VAN ROOYEN 